Volume 2, Nomor 1, February 2020, p. 187 - 192

ISSN 2655-9951 (print), ISSN 2656-0062 (online)

\title{
Corona virus diseases (Covid-19); Sebuah tinjauan literatur
}

\author{
Yuliana $^{*)}$ \\ Fakultas Kedokteran Universitas Lampung \\ Email: ylianaa98@gmail.com
}

\begin{tabular}{|c|c|}
\hline ARTICLE INFO & A B STRACT \\
\hline $\begin{array}{l}\text { *) corresponding author } \\
\text { Mahasiswa, Fakultas Kedokteran, } \\
\text { Universitas Lampung } \\
\text { Jl.Prof. Dr. Ir. Sumantri Brojonegoro No. 1, } \\
\text { Gedong Meneng, Kec. Rajabasa, Kota } \\
\text { Bandarlampung, } 35145 \text { Indonesia }\end{array}$ & $\begin{array}{l}\text { Coronavirus Disease (Covid-19). In 2020, a new type of coronavirus } \\
\text { (SARS-CoV-2) was spread, called a disease called Coronavirus disease } \\
2019 \text { (COVID-19). This virus was discovered in Wuhan, China for the } \\
\text { first time and has infected 90,308 people as of March 2, 2020. The } \\
\text { number of deaths reached 3,087 people or } 6 \% \text {, the number of patients } \\
\text { recovering 45,726 people. This type of single positive RNA strain } \\
\text { infects the human respiratory tract and is sensitive to heat and can } \\
\text { effectively be activated by chlorine-containing disinfectants. The source } \\
\text { of the host is thought to come from animals, especially bats, and other } \\
\text { vectors such as bamboo rats, camels and ferrets. Common symptoms } \\
\text { include fever, cough and difficulty breathing. Clinical syndrome is } \\
\text { divided into uncomplicated, mild pneumonia and severe pneumonia. } \\
\text { Specimen examination is taken from the throat swab (nasopharynx and } \\
\text { oropharynx) and lower airway (sputum, bronchial rinse, endotracheal } \\
\text { aspirate). Isolation was carried out on patients proven to be infected } \\
\text { with Covid-19 to prevent wider spread. }\end{array}$ \\
\hline
\end{tabular}

This is an open access article under the CC-BY-SA license.

\section{PENDAHULUAN}

Diawal tahun 2020, dunia digemparkan dengan merebaknya virus baru yaitu coronavirus jenis baru (SARS-CoV-2) dan penyakitnya disebut Coronavirus disease 2019 (COVID-19). Diketahui, asal mula virus ini berasal dari Wuhan, Tiongkok. Ditemukan pada akhir Desember tahun 2019. Sampai saat ini sudah dipastikan terdapat 65 negara yang telah terjangkit virus satu ini. (Data WHO, 1 Maret 2020) (PDPI, 2020).

Pada awalnya data epidemiologi

menunjukkan $66 \%$ pasien berkaitan atau terpajan dengan satu pasar seafood atau live market di Wuhan, Provinsi Hubei Tiongkok (Huang, et.al., 2020). Sampel isolat dari pasien diteliti dengan 
hasil menunjukkan adanya infeksi coronavirus, jenis betacoronavirus tipe baru, diberi nama 2019 novel Coronavirus (2019-nCoV). Pada tanggal 11 Februari 2020,

World Health Organization memberi nama virus baru tersebut Severe acute respiratory syndrome coronavirus-2 (SARS-CoV-2) dan nama penyakitnya sebagai Coronavirus disease 2019 (COVID19) (WHO, 2020). Pada mulanya transmisi virus ini belum dapat ditentukan apakah dapat melalui antara manusia-manusia. Jumlah kasus terus bertambah seiring dengan waktu. Selain itu, terdapat kasus 15 petugas medis terinfeksi oleh salah satu pasien. Salah satu pasien tersebut dicurigai kasus "super spreader". (Channel News Asia, 2020). Akhirnya dikonfirmasi bahwa transmisi pneumonia ini dapat menular dari manusia ke manusia (Relman, 2020). Sampai saat ini virus ini dengan cepat menyebar masih misterius dan penelitian masih terus berlanjut.

Saat ini ada sebanyak 65 negara terinfeksi virus corona. Menurut data WHO per tanggal 2 Maret 2020 jumlah penderita 90.308 terinfeksi Covid-19. Di Indonesia pun sampai saat ini terinfeksi 2 orang. Angka kematian mencapai 3.087 atau 2.3\% dengan angka kesembuhan 45.726 orang. Terbukti pasien konfrimasi Covid-19 di Indonesia berawal dari suatu acara di Jakarta dimana penderita kontak dengan seorang warga negara asing (WNA) asal jepang yang tinggal di malaysia. Setelah pertemuan tersebut penderita mengeluhkan demam, batuk dan sesak napas (WHO, 2020).

Berdasarkan data sampai dengan 2 Maret 2020, angka mortalitas di seluruh dunia 2,3\% sedangkan khusus di kota Wuhan adalah 4,9\%, dan di provinsi Hubei 3,1\%. Angka ini diprovinsi lain di Tiongkok adalah 0,16\%.8,9 Berdasarkan penelitian terhadap 41 pasien pertama di Wuhan terdapat 6 orang meninggal (5 orang pasien di ICU dan 1 orang pasien non-ICU) (Huang, et.al., 2020). Kasus kematian banyak pada orang tua dan dengan penyakit penyerta. Kasus kematian pertama pasien lelaki usia 61 tahun dengan penyakit penyerta tumor intraabdomen dan kelainan di liver (The Straits Time, 2020).

Kejadian luar biasa oleh Coronavirus bukanlah merupakan kejadian yang pertama kali. Tahun 2002 severe acute respiratory syndrome (SARS) disebakan oleh SARS-coronavirus (SARS-CoV) dan penyakit Middle East respiratory syndrome (MERS) tahun 2012

disebabkan oleh MERS-Coronavirus (MERS-CoV) dengan total akumulatif kasus sekitar 10.000 (1000-an kasus MERS dan 8000-an kasus SARS). Mortalitas akibat SARS sekitar 10\% sedangkan MERS lebih tinggi yaitu sekitar 40\%. (PDPI, 2020).

\section{METODE}

Jurnal laporan kasus diambil dari kasus yang ada di puskesmas dan referensi dari berbagai sumber dari (Medscape, emedicine, data WHO dan lain-lain) kemudian diambil ringkasan dari sumber tersebut yang dijadikan satu menjadi bahan bacaan.

\section{HASIL DAN PEMBAHASAN}

Coronavirus merupakan virus RNA strain tunggal positif, berkapsul dan tidak bersegmen. Coronavirus tergolong ordo Nidovirales, keluarga Coronaviridae. Struktur coronavirus membentuk struktur seperti kubus dengan protein $\mathrm{S}$ berlokasi di

permukaan virus. Protein $\mathrm{S}$ atau spike protein merupakan salah satu protein antigen utama virus dan merupakan struktur utama untuk penulisan gen. Protein $S$ ini berperan dalam penempelan dan masuknya virus kedalam sel host (interaksi protein $\mathrm{S}$ dengan reseptornya di sel inang) (Wang, 2020). Coronavirus bersifat sensitif terhadap panas dan secara efektif dapat diinaktifkan oleh desinfektan mengandung klorin, pelarut lipid dengan suhu $56^{\circ} \mathrm{C}$ selama 30 menit, eter, alkohol, 
asam perioksiasetat, detergen non-ionik, formalin, oxidizing agent dan kloroform. Klorheksidin tidak efektif dalam menonaktifkan virus (Wang, 2020; Korsman, 2012).

\section{Patogenesis dan Patofisiologi}

Kebanyakan Coronavirus menginfeksi hewan dan bersirkulasi di hewan. Coronavirus menyebabkan sejumlah besar penyakit pada hewan dan kemampuannya menyebabkan penyakit berat pada hewan seperti babi, sapi, kuda, kucing dan ayam. Coronavirus disebut dengan virus zoonotik yaitu virus yang ditransmisikan dari hewan ke manusia. Banyak hewan liar yang dapat membawa patogen dan bertindak sebagai vektor untuk penyakit menular tertentu. Kelelawar, tikus bambu, unta dan musang merupakan host yang biasa ditemukan untuk Coronavirus. Coronavirus pada kelelawar merupakan sumber utama untuk kejadian severe acute respiratorysyndrome (SARS) dan Middle East respiratory syndrome (MERS) (PDPI, 2020).

Coronavirus hanya bisa memperbanyak diri melalui sel host-nya. Virus tidak bisa hidup tanpa sel host. Berikut siklus dari Coronavirus setelah menemukan sel host sesuai tropismenya. Pertama, penempelan dan masuk virus ke sel host diperantarai oleh Protein $\mathrm{S}$ yang ada dipermukaan virus.5 Protein S penentu utama dalam menginfeksi spesies host-nya serta penentu tropisnya (Wang, 2020). Pada studi SARS-CoV protein $\mathrm{S}$ berikatan dengan reseptor di sel host yaitu enzim ACE-2 (angiotensin-converting enzyme 2). ACE-2 dapat ditemukan pada mukosa oral dan nasal, nasofaring, paru, lambung, usus halus, usus besar, kulit, timus, sumsum tulang, limpa, hati, ginjal, otak, sel epitel alveolar paru, sel enterosit usus halus, sel endotel arteri vena, dan sel otot polos.20 Setelah berhasil masuk selanjutnya translasi replikasi gen dari RNA genom virus. Selanjutnya replikasi dan transkripsi dimana sintesis virus RNA melalui translasi dan perakitan dari kompleks replikasi virus. Tahap selanjutnya adalah perakitan dan rilis virus (Fehr, 2015).Berikut gambar siklus hidup virus (gambar 1).

Setelah terjadi transmisi, virus masuk ke saluran napas atas kemudian bereplikasi di sel epitel saluran napas atas (melakukan siklus hidupnya). Setelah itu menyebar ke saluran napas bawah. Pada infeksi akut terjadi peluruhan virus dari saluran napas dan virus dapat berlanjut meluruh beberapa waktu di sel gastrointestinal setelah penyembuhan. Masa inkubasi virus sampai muncul penyakit sekitar 3-7 hari (PDPI, 2020).

\section{Manifestasi Klinis}

Infeksi COVID-19 dapat menimbulkan gejala ringan, sedang atau berat. Gejala klinis utama yang muncul yaitu demam (suhu >380C), batuk dan kesulitan bernapas. Selain itu dapat disertai dengan sesak memberat, fatigue, mialgia, gejala gastrointestinal seperti diare dan gejala saluran napas lain. Setengah dari pasien timbul sesak dalam satu minggu. Pada kasus berat perburukan secara cepat dan progresif, seperti ARDS, syok septik, asidosis metabolik yang sulit dikoreksi dan

perdarahan atau disfungsi sistem koagulasi dalam beberapa hari. Pada beberapa pasien, gejala yang muncul ringan, bahkan tidak disertai dengan demam. Kebanyakan pasien memiliki prognosis baik, dengan sebagian kecil dalam kondisi kritis bahkan meninggal. Berikut sindrom klinis yang dapat muncul jika terinfeksi. (PDPI, 2020). Berikut sindrom klinis yang dapat muncul jika terinfeksi. (PDPI, 2020)

a. Tidak berkomplikasi

Kondisi ini merupakan kondisi teringan. Gejala yang muncul berupa gejala yang tidak spesifik. Gejala utama tetap muncul seperti demam, batuk, dapat disertai dengan nyeri tenggorok, kongesti hidung, malaise, sakit kepala, dan nyeri otot. Perlu diperhatikan bahwa pada pasien dengan lanjut usia dan pasien immunocompromises presentasi gejala menjadi tidak khas atau atipikal. Selain itu, pada beberapa kasus ditemui tidak disertai dengan demam dan gejala relatif 
ringan. Pada kondisi ini pasien tidak memiliki gejala komplikasi diantaranya dehidrasi, sepsis atau napas pendek.

b. Pneumonia ringan

Gejala utama dapat muncul seperti demam, batuk, dan sesak. Namun tidak ada tanda pneumonia berat. Pada anak-anak dengan pneumonia tidak berat ditandai dengan batuk atau susah bernapas

c. Pneumonia berat. Pada pasien dewasa:

- Gejala yang muncul diantaranya demam atau curiga infeksi saluran napas

- Tanda yang muncul yaitu takipnea (frekuensi napas: > 30x/menit), distress pernapasan berat atau saturasi oksigen pasien $<90 \%$ udara luar. 26

\section{Penegakkan Diagnosis}

Pada anamnesis gejala yang dapat ditemukan yaitu, tiga gejala utama: demam, batuk kering (sebagian kecil berdahak) dan sulit bernapas atau sesak.

a. Pasien dalam pengawasan atau kasus suspek / possible

1. Seseorang yang mengalami:

a. Demam ( $\geq 380 \mathrm{C})$ atau riwayat demam

b. Batuk atau pilek atau nyeri tenggorokan

c. Pneumonia ringan sampai berat berdasarkan klinis dan/atau gambaran radiologis. (pada pasien immunocompromised presentasi kemungkinan atipikal) DAN disertai minimal satu kondisi sebagai berikut :

- Memiliki riwayat perjalanan ke Tiongkok atau wilayah/ negara yang terjangkit* dalam 14 hari sebelum timbul gejala

- Petugas kesehatan yang sakit dengan gejala sama setelah merawat pasien infeksi saluran pernapasan akut (ISPA) berat yang tidak diketahui penyebab / etiologi penyakitnya, tanpa memperhatikan riwayat bepergian atau tempat tinggal.29

2. Pasien infeksi pernapasan akut dengan tingkat keparahan ringan sampai berat dan salah satu berikut dalam 14 hari sebelum onset gejala:

a. Kontak erat dengan pasien kasus terkonfirmasi atau probable COVID-19, ATAU

b. Riwayat kontak dengan hewan penular (jika hewan sudah teridentifikasi), ATAU

c. bekerja atau mengunjungi fasilitas layanan kesehatan dengan kasus terkonfirmasi atau probable infeksi COVID-19 di Tiongkok atau wilayah/negara yang terjangkit.*

d. Memiliki riwayat perjalanan ke Wuhan dan memiliki demam (suhu $\geq 380 \mathrm{C}$ ) atau riwayat demam.29

b. Orang dalam Pemantauan

Seseorang yang mengalami gejala demam atau riwayat demam tanpa pneumonia yang memiliki riwayat perjalanan ke Tiongkok atau wilayah/negara yang terjangkit, dan tidak memiliki satu atau lebih riwayat paparan diantaranya:

- Riwayat kontak erat dengan kasus konfirmasi COVID-19

- Bekerja atau mengunjungi fasilitas kesehatan yang berhubungan dengan pasien konfirmasi COVID-19 di Tiongkok atau wilayah/negara yang terjangkit (sesuai dengan perkembangan penyakit),

- Memiliki riwayat kontak dengan hewan penular (jika hewan penular sudah teridentifikasi) di Tiongkok atau wilayah/negara yang terjangkit (sesuai dengan perkembangan penyakit 


\section{c. Kasus Probable}

Pasien dalam pengawasan yang diperiksakan untuk COVID-19 tetapi inkonklusif atau tidak dapat disimpulkan atau seseorang dengan hasil konfirmasi positif pan-coronavirus atau beta coronavirus. 29,30

d. Kasus terkonfirmasi

Seseorang yang secara laboratorium terkonfirmasi COVID-19.

\section{Pemeriksaan Penunjang (PDPI, 2020)}

1. Pemeriksaan radiologi: foto toraks, CT-scan toraks, USG toraks. Pada pencitraan dapat menunjukkan: opasitas bilateral, konsolidasi subsegmental, lobar atau kolaps paru atau nodul, tampilan groundglass.

2. Pemeriksaan spesimen saluran napas atas dan bawah

- Saluran napas atas dengan swab tenggorok(nasofaring dan orofaring)

- Saluran napas bawah (sputum, bilasan bronkus, BAL, bila menggunakan endotrakeal tube dapat berupa aspirat endotrakeal

3. Bronkoskopi

4. Pungsi pleura sesuai kondisi

5. Pemeriksaan kimia darah

6. Biakan mikroorganisme dan uji kepekaan dari bahan saluran napas (sputum, bilasan bronkus, cairan pleura) dan darah26,27 Kultur darah untuk bakteri dilakukan, idealnya sebelum terapi antibiotik. Namun, jangan menunda terapi antibiotik dengan menunggu hasil kultur darah)26

7. Pemeriksaan feses dan urin (untuk investasigasi kemungkinan penularan).

\section{Tatalaksana Umum}

1. Isolasi pada semua kasus

Sesuai dengan gejala klinis yang muncul, baik ringan maupun sedang.

2. Implementasi pencegahan dan pengendalian infeksi (PPI) 26

3. Serial foto toraks untuk menilai perkembangan penyakit 27

4. Suplementasi oksigen

Pemberian terapi oksigen segera kepada pasien dengan, distress napas, hipoksemia atau syok. Terapi oksigen pertama sekitar $5 \mathrm{~L} /$ menit dengan target $\mathrm{SpO} 2 \geq 90 \%$ pada pasien tidak hamil dan $\geq 92-95 \%$ pada pasien hamil

5. Kenali kegagalan napas hipoksemia berat

6. Terapi cairan

Terapi cairan konservatif diberikan jika tidak ada bukti syok Pasien dengan SARI harus diperhatikan dalam terapi cairannya, karena jika pemberian cairan terlalu agresif dapat memperberat kondisi distress napas atau oksigenasi. Monitoring keseimbangan cairan dan elektrolit

7. Pemberian antibiotik empiris

8. Terapi simptomatik

Terapi simptomatik diberikan seperti antipiretik, obat batuk dan lainnya jika memang diperlukan.

9. Pemberian kortikosteroid sistemik tidak rutin diberikan pada tatalaksana pneumonia viral atau ARDS selain ada indikasi lain.

10. Observasi ketat

11. Pahami komorbid pasien

Saat ini belum ada penelitian atau bukti talaksana spesifik pada COVID-19. Belum ada tatalaksana antiviral untuk infeksi Coronavirus yang terbukti efektif. Pada studi terhadap SARSCoV, kombinasi 
lopinavir dan ritonavir dikaitkan dengan memberi manfaat klinis. Saat ini penggunaan lopinavir dan ritonavir masih diteliti terkait efektivitas dan keamanan pada infeksi COVID-19. Tatalaksana yang belum teruji / terlisensi hanya boleh diberikan dalam situasi uji klinis yang disetujui oleh komite etik atau melalui Monitored Emergency Use of Unregistered Interventions Framework (MEURI), dengan pemantauan ketat. Selain itu, saat ini belum ada vaksin untuk mencegah pneumonia COVID-19 ini (PDPI, 2020).

\section{SIMPULAN DAN SARAN}

Covid-19 merupakan infeksi virus baru yang mengakibatkan terinfeksinya 90.308 orang per tanggal 2 Maret 2020. Virus ini bermula di Wuhan, China pada 31 Desember 2019. Virus yang merupakan virus RNA strain tunggal positif ini menginfeksi saluran pernapasan. Penegakan diagnosis dimulai dari gejala umum berupa demam, batuk dan sulit bernapas hingga adanya kontak erat dengan negara-negara yang sudah terifinfeksi. Pengambilan swab tenggorokan dan saluran napas menjadi dasar penegakan diagnosis coronavirus disease. Penatalaksanaan berupa isolasi harus dilakukan untuk mencegah penyebaran lebih lanjut.

\section{DAFTAR PUSTAKA}

Channel News Asia. (2020). Wuhan virus outbreak: 15 medical workers infected, 1 in critical condition. [Homepage on The Internet]. Cited Jan 28th 2020. Available on:https://www.channelnewsasia.com/news/asia/wuhanpneumonia-outbreak-health-workerscoronavirus-12294212

Fehr, A.R., Perlman, S. (2015). Coronavirus: An Overview of Their Replication and Pathogenesis. Methods Mol Biol. 2015 ; 1282: 1-5

Huang, C., Wang, Y., Li, X., Ren, L., Zhao „J., Zan,g Li., Fan, G., etc. (2020). Clinical features of patients infected with 2019 novel coronavirus in Wuhan, China. The Lancet. 24 jan 2020.

Korsman, S.N.J., van Zyl, G.U., Nutt, L., Andersson, M.I, Presier, W. (2012). Viroloy. Chins: Churchill Livingston Elsevier

Perhimpunan Dokter Paru Indonesia. (2020). Panduan Praktik Klinis: Pneumonia 2019-nCoV. PDPI: Jakarta

Relman, E. (2020). Business insider Singapore. Cited Jan 28th 2020. Available on:https://www.businessinsider.sg/deadly-china-wuhan-virusspreading- human-to-humanofficials-confirm-2020- 1/?r=US\&IR=T.

WHO. (2020). WHO Director-General's remarks at the media briefing on 2019-nCov on 11 February 2020. Cited Feb 13rd 2020. Available on: https://www.who.int/dg/speeches/detail/who-director-generals- $\quad$ remarks-at-the-mediabriefing-on-2019-ncov-on-11-february- 2020. (Feb 12th 2020)

Wang, Z., Qiang, W., Ke, H. (2020). A Handbook of 2019-nCoV Pneumonia Control and Prevention. Hubei Science and Technologi Press. China 